\title{
Promotion Effect of Alkali Metal Hydroxides on Polymer-Stabilized Pd Nanoparticles for Selective Hydrogenation of C-C Triple Bonds in Alkynols
}

\author{
Linda Zh. Nikoshvili, ${ }^{*}{ }^{\dagger}$ Alexey V. Bykov, ${ }^{\dagger}$ Tatiana E. Khudyakova, ${ }^{\dagger}$ Thomas LaGrange, $^{\dagger}$ \\ Florent Héroguel, ${ }^{\S}$ Jeremy S. Luterbacher, ${ }^{\S}{ }^{\circ}$ Valentina G. Matveeva, ${ }^{\dagger}$ Esther M. Sulman, \\ Paul J. Dyson, ${ }^{\circ}$ and Lioubov Kiwi-Minsker*, $\|^{\circ} \perp$
}

${ }^{\dagger}$ Department of Biotechnology and Chemistry, Tver Technical University, A. Nikitina Street, 22, 170026, Tver, Russia

${ }^{\ddagger}$ Interdisciplinary Centre for Electron Microscopy (CIME), ${ }^{\S}$ Laboratory of Sustainable and Catalytic Processing, and "Laboratory of Organometallic and Medical Chemistry, Ecole Polytechnique Fédérale de Lausanne (EPFL), CH-1015, Lausanne, Switzerland

${ }^{\perp}$ Tver State University, Regional Technological Center, Zhelyabova Street, 33, 170100, Tver, Russia

\section{Supporting Information}

ABSTRACT: Postimpregnation of Pd nanoparticles (NPs) stabilized within hyper-cross-linked polystyrene with sodium or potassium hydroxides of optimal concentration was found to significantly increase the catalytic activity for the partial hydrogenation of the $\mathrm{C}-\mathrm{C}$ triple bond in 2-methyl-3-butyn-2ol at ambient hydrogen pressure. The alkali metal hydroxide accelerates the transformation of the residual $\mathrm{Pd}(\mathrm{II})$ salt into $\operatorname{Pd}(0)$ NPs and diminishes the reaction induction period. In addition, the selectivity to the desired 2-methyl-3-buten-2-ol increases with the $\mathrm{K}$ - and $\mathrm{Na}$-doped catalysts from 97.0 up to 99.5\%. This effect was assigned to interactions of the alkali metal ions with the Pd NPs surfaces resulting in the sites' separation and a change of reactants adsorption.

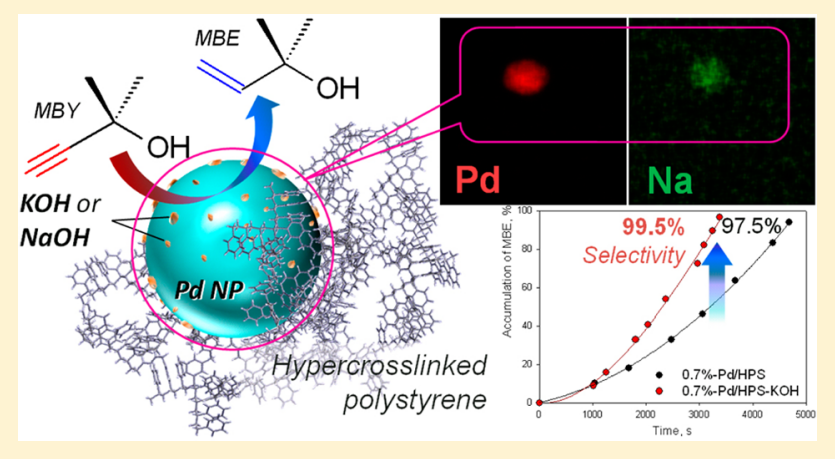

\section{INTRODUCTION}

Pd-catalyzed selective hydrogenations of the carbon-carbon triple bond in alkynols is an important reaction in the production of fine chemicals such as fragrances (linalool, terpineol, geraniol, citral, etc.), pharmaceuticals, and fat-soluble vitamins (e.g., E, K). ${ }^{1,2}$ Industrial alkynol hydrogenation is usually carried out as a 3-phase reaction using the Lindlar catalyst $\left(\mathrm{Pd} / \mathrm{CaCO}_{3}\right.$ doped with lead acetate) in the presence of quinolone, employed as liquid-phase modifier. This system delivers a selectivity around $95 \%$ at close to $100 \%$ conversion. ${ }^{1,3,4}$ However, the modifiers can contaminate the target product, which is unacceptable to the pharmaceutical and food industries.

Despite numerous achievements in the development of alternative catalysts to the industrial Lindlar catalytic process, ${ }^{4}$ attaining high selectivity with reasonable activity/stability (especially in the case of alkynols containing terminal $\mathrm{C}-\mathrm{C}$ triple bonds) remains challenging and requires careful selection of the catalyst and optimization of the reaction conditions.

There are several ways to improve catalyst efficiency in hydrogenations of triple bonds, for example, adjusting the size and morphology of Pd nanoparticles (NPs), ${ }^{5}$ with small Pd NPs known to be selective due to the absence of a $\beta$-hydride phase, ${ }^{6}$ and/or the addition of a second metal to the Pd NP system. There are two main ways to improve selectivity, also involving addition of a second metal to form bimetallic alloyed NPs and/or the addition of promoters, surface dopants, or modifiers. It is noteworthy that "catalytic poisons" such as $\mathrm{Pb}$ and $\mathrm{Sn}$, and other metals such as $\mathrm{Na}, \mathrm{K}, \mathrm{Zn}, \mathrm{Ag}, \mathrm{Au}$, etc., may be used. For example, it was shown that the addition of $\mathrm{Ag}$ results in the formation of alloyed Ag-Pd NPs and a selectivity of $96 \%$ for the partially hydrogenated product of dehydroisophytol (cf. Pd NPs which exhibit a selectivity of 78\%).

Alkali metal cations are known promoters of Pd-containing hydrogenation catalysts, ${ }^{8-15}$ often incorporated by postimpregnation of Pd-catalyst with aqueous solutions containing alkali metal cations with subsequent reduction in a hydrogen atmosphere. $^{8-10}$ Cho et al. have shown that postimpregnation provides enhanced catalytic activity of the target product in the hydrogenation of biphenol over $\mathrm{Pd} / \mathrm{C}$ in comparison to preimpregnated and coimpregnated catalysts. It was suggested

Special Issue: Tapio Salmi Festschrift

Received: April 17, 2017

Revised: July 19, 2017

Accepted: July 21, 2017

Published: July 21, 2017 
Table 1. MBY Hydrogenation over the 0.7\%-Pd/MN100 Catalysts ${ }^{a}$

\begin{tabular}{|c|c|c|c|c|}
\hline$N$ & catalyst & modifier & $S_{\mathrm{MBE}} \pm 0.5, \%\left(X_{\mathrm{MBY}}=95 \%\right)$ & $R \pm 0.1, \mathrm{~mol}_{\mathrm{MBY}} \cdot \mathrm{mol}^{-1}{ }_{\mathrm{Pd}} \cdot \mathrm{s}^{-1}$ \\
\hline 1 & $0.7 \%-\mathrm{Pd} / \mathrm{MN} 100$ & none & 97.5 & 4.2 \\
\hline 2 & $0.7 \%-\mathrm{Pd} / \mathrm{MN} 100-\mathrm{R}$ & none & 95.0 & 4.1 \\
\hline 3 & $0.7 \%-\mathrm{Pd} / \mathrm{MN} 100-\mathrm{w}$ & treated with $\mathrm{H}_{2} \mathrm{O}$ & 97.0 & 3.7 \\
\hline 4 & $0.7 \%-\mathrm{Pd} / \mathrm{MN} 100-\mathrm{Na}$ & $\mathrm{NaOH}, 0.5 \mathrm{~mol} / \mathrm{L}$ & 99.0 & 5.9 \\
\hline 5 & $0.7 \%-\mathrm{Pd} / \mathrm{MN} 100-\mathrm{K}-1$ & $\mathrm{KOH}, 0.1 \mathrm{~mol} / \mathrm{L}$ & 99.5 & 3.6 \\
\hline 6 & $0.7 \%-\mathrm{Pd} / \mathrm{MN} 100-\mathrm{K}-2$ & $\mathrm{KOH}, 0.25 \mathrm{~mol} / \mathrm{L}$ & 98.5 & 4.6 \\
\hline 7 & $0.7 \%-\mathrm{Pd} / \mathrm{MN} 100-\mathrm{K}-3$ first use & $\mathrm{KOH}, 0.5 \mathrm{~mol} / \mathrm{L}$ & 99.0 & 7.1 \\
\hline 8 & $0.7 \%-\mathrm{Pd} / \mathrm{MN} 100-\mathrm{K}-3$ first use without in situ reduction & & 99.0 & 5.2 \\
\hline 9 & 0.7\%-Pd/MN100-K-3 second use & & 98.0 & 3.8 \\
\hline 10 & $0.7 \%-\mathrm{Pd} / \mathrm{MN} 100-\mathrm{K}-3$ modified additionally after the first use & & 99.0 & 3.3 \\
\hline 11 & 0.7\%-Pd/MN100-R-K-3 & & 98.5 & 2.0 \\
\hline 12 & $0.7 \%-\mathrm{Pd} / \mathrm{MN} 100-\mathrm{K}-3-\mathrm{R}$ & & 94.5 & 6.0 \\
\hline 13 & $0.7 \%-\mathrm{Pd} / \mathrm{MN} 100-\mathrm{K}-4$ & $\mathrm{KOH}, 1.0 \mathrm{~mol} / \mathrm{L}$ & 98.5 & 4.3 \\
\hline
\end{tabular}

${ }^{a}$ Reaction conditions: toluene $(30 \mathrm{~mL}), 90{ }^{\circ} \mathrm{C}$, MBY concentration $0.6 \mathrm{~mol} / \mathrm{L}(1.5 \mathrm{~g})$, Pd concentration $4.4 \times 10^{-5} \mathrm{~mol} / \mathrm{L}(0.02 \mathrm{~g}$ of the catalyst).

that postimpregnation results in the alkali metal being located in the vicinity of the catalytically active Pd NPs. ${ }^{10}$

Pellegrini et al. demonstrate a promotion effect of $\mathrm{K}_{2} \mathrm{CO}_{3}$ on a $\mathrm{Pd} / \mathrm{SiO}_{2}-\mathrm{Al}_{2} \mathrm{O}_{3}$ catalyst, which leads to the formation of mixed K/Pd-oxides even at low potassium content. ${ }^{8}$ It should be emphasized that the formation of a mixed oxide phase is possible only at high temperatures $\left(>500{ }^{\circ} \mathrm{C}\right) .{ }^{16}$ Alkali metal salts can also influence the mobility of Pd NPs on solid supports, thus preventing sintering during thermal treatments. ${ }^{8,10}$ It is noteworthy that in contrast to the results of Pellegrini et al., ${ }^{8}$ Jia et al. ${ }^{9}$ did not find any mixed $\mathrm{Pd} / \mathrm{K}$ containing species. However, K-containing species either on the Pd NPs, in the form of islands, or at the interface between Pd and the support were not excluded. ${ }^{9}$ This so-called "geometric effect" of alkali metal ions may help preserve catalytically active Pd NPs from sintering during catalyst reduction at high temperatures. However, due to the geometric effect, alkali metal ions, especially at high loadings, may decrease the catalytic activity by blocking active sites. 10

There are also other reasons of adding alkali metal salts to Pd-containing catalysts, for example, they help to avoid $\mathrm{HCl}$ accumulation during hydrodechlorination processes. $^{12-14}$ In the case of hydrodechlorination of chlorobenzene, Aramendia et al. have shown that the presence of $\mathrm{Na}^{+}$ions in the vicinity of the Pd NPs facilitates chlorobenzene adsorption by capturing the chloride with the formation of $\mathrm{NaCl}^{12}$ However, only highly dispersed palladium can benefit from the addition of NaOH. ${ }^{13}$

Herein, we present the beneficial effects of postimpregnation of Pd NPs catalyst based on hyper-cross-linked polystyrene (HPS) by aqueous solutions of alkali metal hydroxides $(\mathrm{NaOH}$ and $\mathrm{KOH}$ ). The Pd/HPS catalyst was previously shown to be promising catalyst for the partial hydrogenation of triple $\mathrm{C}-\mathrm{C}$ bonds in alkynols. ${ }^{17-19}$

The nature of the Pd precursor and the type of HPS (functionalized or without any functional groups) strongly influences the activity of HPS-based catalysts. In our previous work, MN100-type HPS impregnated with $\mathrm{PdCl}_{2}\left(\mathrm{CH}_{3} \mathrm{CN}\right)_{2}$ and reduced in situ with hydrogen was shown to be the most efficient catalyst leading to a selectivity of $\sim 98 \%$, with reasonable activity, in the partial hydrogenation of 2-methyl3-butyn-2-ol (MBY). ${ }^{17}$ However, independent of the nature of the precursor, the catalysts based on the MN100 support show an induction period in spite of an in situ catalyst activation procedure. In the present study we address the question of the induction period and the influence of alkali metal hydroxides on this phenomenon in order to optimize the catalytic efficiency (activity and selectivity) of the Pd/HPS catalysts.

\section{EXPERIMENTAL SECTION}

Materials. HPS Macronet MN100 (Purolite Int., United Kingdom) was washed with distilled water and acetone and dried under vacuum as described elsewhere. ${ }^{20}$ 2-Methyl-3butyn-2-ol (MBY, >99\%), 2-methyl-3-buten-2-ol (MBE, $>97 \%$ ), 2-methyl-2-butanol (MBA, >96\%), bis(acetonitrile)palladium(II)chloride $\left(\mathrm{PdCl}_{2}\left(\mathrm{CH}_{3} \mathrm{CN}\right)_{2},>99 \%\right)$, tetrahydrofuran (THF, $\geq 99.9 \%)$, toluene $(99.8 \%)$, potassium hydroxide $(\mathrm{KOH}, \geq 85 \%)$, sodium carbonate $\left(\mathrm{Na}_{2} \mathrm{CO}_{3}, \geq 99.5 \%\right)$ and sodium hydroxide $(\mathrm{NaOH}, \geq 98 \%)$ were obtained from SigmaAldrich. All chemicals were used as received. Distilled water was purified with an Elsi-Aqua water purification system.

Catalyst Synthesis. Pd/MN100 catalyst was synthesized via the conventional wet-impregnation method according to the procedure described elsewhere. ${ }^{20}$ In a typical experiment, $3 \mathrm{~g}$ of pretreated, dried, and crushed $(<63 \mu \mathrm{m})$ granules of HPS were impregnated with $9 \mathrm{~mL}$ of the $\mathrm{PdCl}_{2}\left(\mathrm{CH}_{3} \mathrm{CN}\right)_{2}$ THF solution (concentration $0.022 \mathrm{~mol} / \mathrm{L}$ ). The $\mathrm{Pd}$-containing polymer was dried at $70{ }^{\circ} \mathrm{C}$, treated with $8.5 \mathrm{~mL}$ of $\mathrm{Na}_{2} \mathrm{CO}_{3}$ aqueous solution (concentration $0.08 \mathrm{~mol} / \mathrm{L}$ ) and dried until a constant weight was achieved. It was expected that such a treatment would lead to hydrolysis of $\mathrm{PdCl}_{2}\left(\mathrm{CH}_{3} \mathrm{CN}\right)_{2}$ and precipitation of PdO inside the HPS cavities. The catalyst was washed with distilled water until a $\mathrm{pH}$ of 7 was reached and then dried at 70 ${ }^{\circ} \mathrm{C}$. In this way the catalyst with metal loading of $0.7 \mathrm{wt} \%$ was obtained (designated as $0.7 \%-\mathrm{Pd} / \mathrm{MN} 100$ and used as a reference). This catalyst was also reduced in hydrogen at a $\mathrm{H}_{2}$ flow rate of $100 \mathrm{~mL} / \mathrm{min}$ and a temperature of $300{ }^{\circ} \mathrm{C}$ for 2 $\mathrm{h}$ (designated as $0.7 \%-\mathrm{Pd} / \mathrm{MN} 100-\mathrm{R})$.

The obtained catalysts (i.e., without and with $\mathrm{H}_{2}$ reduction) were modified with $\mathrm{NaOH}$ or $\mathrm{KOH}$ prior to catalysis. In a typical experiment, $0.02 \mathrm{~g}$ of $0.7 \%-\mathrm{Pd} / \mathrm{MN} 100$ or $0.7 \%-\mathrm{Pd} /$ MN100-R was impregnated with $0.09 \mathrm{~mL}$ of alkaline hydroxide solution. In the case of $\mathrm{NaOH}$, a concentration of $0.5 \mathrm{~mol} / \mathrm{L}$ was used (catalyst designated as $0.7 \%-\mathrm{Pd} / \mathrm{MN} 100-\mathrm{Na}$ ), while in the case of $\mathrm{KOH}$ concentrations of $0.1,0.25,0.5$, and $1 \mathrm{~mol} / \mathrm{L}$ were used (catalysts designated as $0.7 \%-\mathrm{Pd} / \mathrm{MN} 100-\mathrm{K}-1,0.7 \%$ $\mathrm{Pd} / \mathrm{MN} 100-\mathrm{K}-2$, 0.7\%-Pd/MN100-K-3, and 0.7\%-Pd/MN100$\mathrm{K}-4$, respectively; see Table 1 ). After modification all the catalysts were dried at $75{ }^{\circ} \mathrm{C}$ for $20 \mathrm{~h}$. 
The $0.7 \%-\mathrm{Pd} / \mathrm{MN} 100$ catalyst was also treated with distilled water (designated as $0.7 \%-\mathrm{Pd} / \mathrm{MN} 100-\mathrm{w}$ ) according to the procedure described above in order to reveal the influence of alkali metal cation.

The possibility of gas-phase reduction of the catalyst modified with $0.5 \mathrm{~mol} / \mathrm{L}$ aqueous solution of $\mathrm{KOH}$ (designated as $0.7 \%-\mathrm{Pd} / \mathrm{MN} 100-\mathrm{K}-3-\mathrm{R}$ ) was also investigated.

The general scheme of the used treatments of the $0.7 \%-\mathrm{Pd} /$ MN100 catalysts is presented in Figure 1.

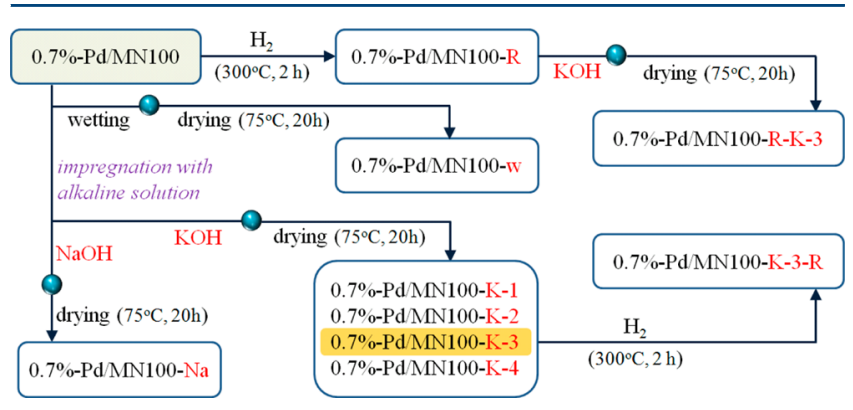

Figure 1. Modification and reduction of $0.7 \%-\mathrm{Pd} / \mathrm{MN} 100$ catalysts.

Additionally, the in situ activation by hydrogen during $60 \mathrm{~min}$ was applied to all catalysts before testing.

Catalyst Testing: Setup, Procedure, and Analytics. Testing of the catalysts in the selective hydrogenation of MBY to $\mathrm{MBE}$ (Figure 2) was performed at $90{ }^{\circ} \mathrm{C}$ in a $60 \mathrm{~mL}$ isothermal glass batch reactor connected to a gasometrical buret for online monitoring of hydrogen consumption, and installed in a shaker for vigorous mixing (more than 800 twosided shaking per minute), which excludes external diffusion limitations. ${ }^{18}$ The internal diffusion limitations were also excluded via powdering of HPS to $<63 \mu \mathrm{m} .^{18,19}$ Toluene was used as a solvent. A recirculating bath (LOIP LT 100, SaintPetersburg, Russia) was used to stabilize the reaction temperature within $\pm 1{ }^{\circ} \mathrm{C}$ using water as the thermal medium. The choice of solvent and reaction temperature was based on previous studies. $^{18,19}$

At the beginning of each experiment, the temperature was set to $90{ }^{\circ} \mathrm{C}$, and allowed to stabilize (ca. $\left.30 \mathrm{~min}\right)$. After that the reactor was charged with catalyst $(0.02 \mathrm{~g})$ and toluene $(15 \mathrm{~mL})$, and hydrogen was then introduced. All catalysts were activated in situ during $60 \mathrm{~min}$ before the MBY addition (time "zero", $t=$ 0 for the reaction). It is noteworthy that the addition of MBY $(0.018 \mathrm{~mol})$ was accompanied by the addition of $15 \mathrm{~mL}$ of toluene, so the total volume of liquid phase was $30 \mathrm{~mL}$. A noninvasive liquid sampling system allowed a controlled removal of aliquots $(0.1-0.5 \mathrm{~mL})$ from the reactor by the syringe and analyzed via GC-MS (Shimadzu GCMSQP2010S) equipped with a capillary column HP-1MS (30 m $\times 0.25 \mathrm{~mm}$ i.d., $0.25 \mu \mathrm{m}$ film thickness). Helium was used as a carrier gas. The concentrations of the substrate/products were determined using an internal standard (diphenylamine) calibration method. Repeated reaction runs with the same catalyst batch delivered concentration values that were reproducible within $\pm 0.5 \%$. The conversion of $M B Y$ is defined as

$$
X_{\mathrm{MBY}}(\%)=\frac{C_{\mathrm{MBY}, 0}-C_{\mathrm{MBY}}}{C_{\mathrm{MBY}, 0}} 100
$$

and selectivity with respect to MBE as the target product, is

$$
S_{\mathrm{MBE}}(\%)=\frac{C_{\mathrm{MBE}}}{C_{\mathrm{MBY}, 0}-C_{\mathrm{MBY}}} 100
$$

Catalytic activity was characterized by the rate of MBY concentration calculated in the range of linear dependency $X$ $\%$ on time (induction as well as slow-down periods were excluded from the calculation), and designated as $R,\left[\mathrm{~mol}_{\mathrm{MBY}}\right.$. $\mathrm{mol}^{-1} \mathrm{Pd}^{-1} \mathrm{~s}^{-1}$.

$R=\left(N_{\mathrm{MBY}, \mathrm{X} 2}-N_{\mathrm{MBY}, \mathrm{X} 1}\right) \times N_{\mathrm{Pd}}^{-1} \times\left(\tau_{2}-\tau_{1}\right)^{-1}$, where $N_{\mathrm{MBY}, \mathrm{X} 2}$ and $N_{\mathrm{MBY}, \mathrm{X} 1}$ are the numbers of moles of $\mathrm{MBY}$ converted at the reaction time $\tau_{2}$ and $\tau_{1}$, respectively; $N_{\mathrm{Pd}}$ is the total number of moles of $\mathrm{Pd}$ participating in the reaction.

Catalyst Characterization. X-ray photoelectron spectroscopy (XPS) data were obtained using $\mathrm{Mg} \mathrm{K} \alpha(h \nu=1253.6 \mathrm{eV})$ radiation on an ES-2403 spectrometer (Institute for Analytic Instrumentation of RAS, St. Petersburg, Russia) equipped with energy analyzer PHOIBOS 100-5MCD (SPECS GmbH, Germany) and X-ray source XR-50 (SPECS GmbH, Germany). All data were acquired at an X-ray power of $250 \mathrm{~W}$. Survey spectra were recorded at an energy step of $0.5 \mathrm{eV}$ with an analyzer pass energy of $40 \mathrm{eV}$. High resolution spectra were recorded at an energy step of $0.05 \mathrm{eV}$ with an analyzer pass energy of $7 \mathrm{eV}$. Samples were allowed to outgas for $180 \mathrm{~min}$ before analysis and were stable during the examination. The data analysis was performed with CasaXPS. The binding energy of C $1 \mathrm{~s}$ of the HPS was taken as $285.0 \mathrm{eV}$. The accuracy of identification of binding energies was $0.1 \mathrm{eV}$.

Pd NPs sizes were evaluated by high-angle annular dark-field scanning transmission electron microscopy (HAADF STEM) using FEI Talos F200S electron microscope working at accelerating voltage of $200 \mathrm{keV}$. Samples were prepared by embedding the catalyst in epoxy resin (EPON 812, polymerization conditions: $24 \mathrm{~h}$ at $333 \mathrm{~K}$ ) with microtomming ( $c$ a. 50 $\mathrm{nm}$ thick) at ambient temperature. A holey carbon/Cu grid (300 mesh) was used as a sample support. The grid was plasma cleaned (for $5 \mathrm{~min}$ ) using a Fischione 1070 plasma cleaner operated at a forward power of $10.45 \mathrm{~W}$ and $30 \mathrm{sccm}$ gas flow. HAADF STEM measurements were accompanied by the EDX analysis.

DRIFT spectra of $\mathrm{CO}$ adsorption were recorded using a high temperature Harrick DRIFT cell on a PerkinElmer Frontier spectrometer equipped with a mercury cadmium telluride detector. The setup enables treatment of the sample with gas flows $\left(\mathrm{He}, \mathrm{H}_{2}, \mathrm{CO}\right)$ and under vacuum from 10 to $500{ }^{\circ} \mathrm{C}$. Spectra were typically collected with 32 scans at a resolution of $4 \mathrm{~cm}^{-1}$.

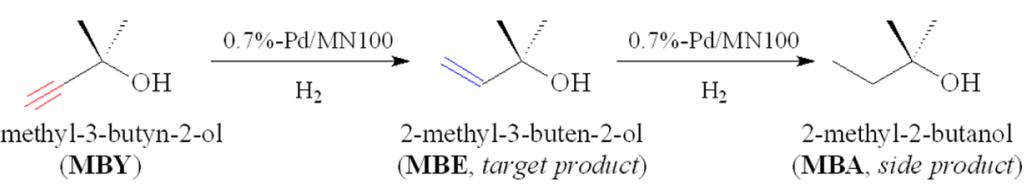

Figure 2. Reaction network of MBY selective hydrogenation to MBE. 

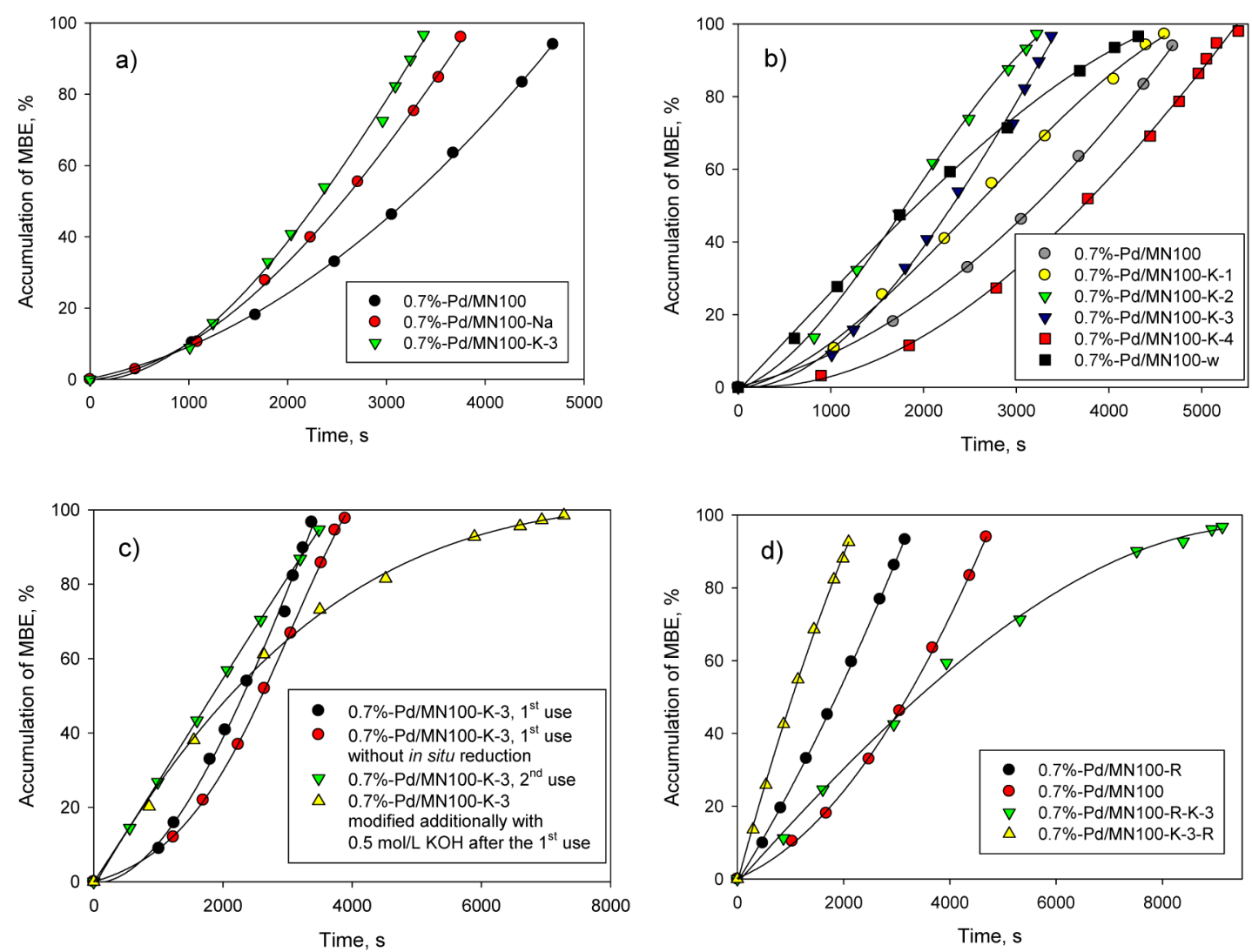

Figure 3. Kinetic curves showing MBE accumulation showing the influence of modifier on the $0.7 \%-\mathrm{Pd} / \mathrm{MN} 100$ catalysts (a), influence of KOH concentration (b), repeated use (c), and influence of gas-phase (hydrogen) reduction (d).

\section{RESULTS AND DISCUSSION}

3.1. Hydrogenation of MBY. The hydrogenation of MBY using Pd/HPS catalysts (Table 1 and Figure 3 ) results in the complete conversion of MBY and overhydrogenation of target product (MBE) to MBA. Thus, the reaction was stopped after reaching $>99 \%$ MBY conversion.

Modification of the reference catalyst $0.7 \%-\mathrm{Pd} / \mathrm{MN} 100$ with $0.5 \mathrm{~mol} / \mathrm{L}$ aqueous solution of $\mathrm{NaOH}$ or $\mathrm{KOH}$ results in an increase in selectivity of the partially reduced MBE product (from $97.5 \%$ to ca. 99\%). A decrease of the induction period accompanied by a ca. 1.4-fold increase of activity (specific transformation rate, $R$ ) was also observed (Figure 3a), presumably due to accelerated active site formation (i.e., more facile reduction of residual $\mathrm{Pd}(\mathrm{II})$ species in the presence of alkali metal hydroxides) during the in situ liquid-phase activation. It is noteworthy that if the in situ activation step is excluded (see Figure 3c), a longer induction period is observed, confirming the proposed nature of induction period and the necessity of in situ reductive activation.

It should also be noted that the catalyst modified by $\mathrm{KOH}$ is more active (the reaction proceeds faster) than the one modified with $\mathrm{NaOH}$ (3a). This difference is in agreement with a study by Lamy-Pitara et al. which showed that the activity of a Pt catalyst in the hydrogenation of double bonds depends on the size of the doping cation. ${ }^{21}$

Figure 4 compares the dependency of selectivity vs conversion for the reference catalyst and $0.7 \%-\mathrm{Pd} / \mathrm{MN} 100-\mathrm{K}$ 3. The higher selectivity was obtained for all MBY conversions up to $X=95 \%$ suggesting that doping with $\mathrm{KOH}$ changes the reaction network and diminishes MBY overhydrogenation.

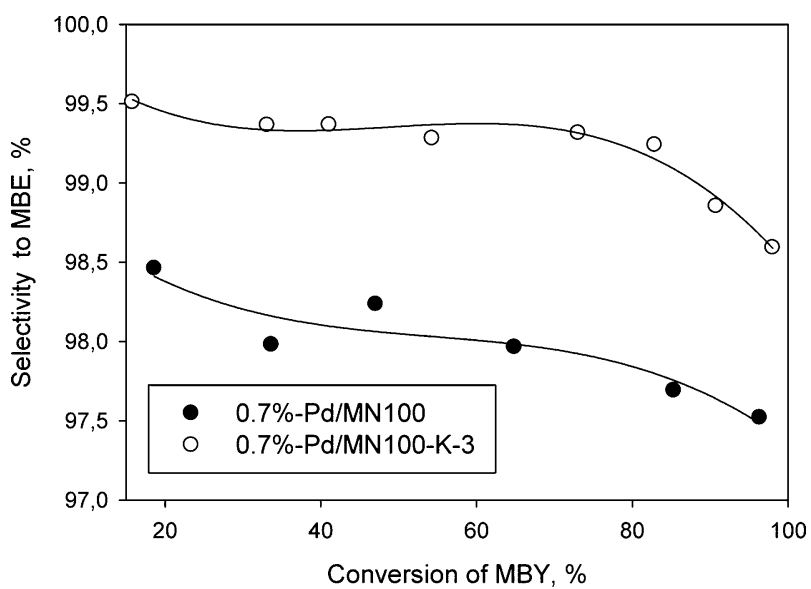

Figure 4. Dependency of selectivity vs conversion of $0.7 \%-\mathrm{Pd} / \mathrm{MN} 100$ and $0.7 \%-\mathrm{Pd} / \mathrm{MN} 100-\mathrm{K}-3$ in the partial hydrogenation of MBY.

The influence of the KOH-modifier concentration was studied (Table 1, no. 5-7 and no. 12; Figure 3b) with the concentration of the $\mathrm{KOH}$ solution decreasing from $1.0 \mathrm{~mol} / \mathrm{L}$ stepwise to $0.1 \mathrm{~mol} / \mathrm{L}$, revealing an influence on the length of the induction period (Figure 3b; Table 1, no. 3), but with the selectivity to MBE remaining almost constant at $99 \pm 0.5 \%$. Only in the case of "zero" concentration of modifier, that is, for 0.7\%-Pd/MN100-w (Table 1, no. 3) does the selectivity decrease to $97.0 \%$ (i.e., for $0.7 \%-\mathrm{Pd} / \mathrm{MN} 100-\mathrm{w}$ ). Thus, the $\mathrm{KOH}$ increases the selectivity and shortens the duration of the induction period as compared to the reference catalyst (see section 3.2). Only at the highest $\mathrm{KOH}$ concentration of $1 \mathrm{~mol} /$ 
$\mathrm{L}$ is the induction period the longest of all the catalysts, with a selectivity of $\sim 98.5 \%$ at $95 \%$ conversion (Table 1 , no. 13 ; Figure $3 \mathrm{~b}$ ). The catalytic activity was observed to increase with the concentration of $\mathrm{KOH}$ passing through the maximum at $\mathrm{KOH} 0.5 \mathrm{~mol} / \mathrm{L}$ (Table 1, no. 7; Figure 3b). It has previously been suggested that at high concentrations the $\mathrm{K}^{+}$ions block the surfaces of the Pd NPs decreasing the reaction rate. ${ }^{10}$

While investigating the adsorption of carbon monoxide and hydrogen on alkali-doped Pd surfaces, ${ }^{22}$ it was found that the adsorption energies vary. Thus, the increase in selectivity and activity observed in the partial hydrogenation of MBY using the $0.7 \%-\mathrm{Pd} / \mathrm{MN} 100-\mathrm{K}-3$ catalyst (doped by alkali metal at optimized concentration) may be attributed to a change in the adsorption equilibrium of hydrogen and/or the substrate.

The stability of the $0.7 \%-\mathrm{Pd} / \mathrm{MN} 100-\mathrm{K}-3$ catalyst was studied by performing repeated reaction runs (see Table 1 , no. 7-9; Figure 3c). After the first run the induction period completely disappears, indicating that the induction period is due to the in situ reduction of palladium and active site formation. The form of the kinetic curve in the case of second reaction run is similar to that observed for prereduced Pd NP catalysts. $^{23}$ After the second run the selectivity of $0.7 \%-\mathrm{Pd} /$ MN100-K-3 slightly decreases from $99.0 \%$ to $98.0 \%$ (Table 1, no. 7 and no. 8). Therefore, the catalyst was treated with additional $\mathrm{KOH}$ after the first run (Table 1, no. 9) and the selectivity remained at $99.0 \%$, albeit at the expense of the reaction rate (see the kinetic curve of MBE accumulation Figure 3c). The investigation of multiple reuses of the catalyst $0.7 \%-\mathrm{Pd} / \mathrm{MN} 100-\mathrm{K}-3$ shows a drop of activity after the first reaction run followed by its stabilization (Figure 5). The selectivity to the desired product MBE remained almost the same $98.5 \pm 0.5 \%$.

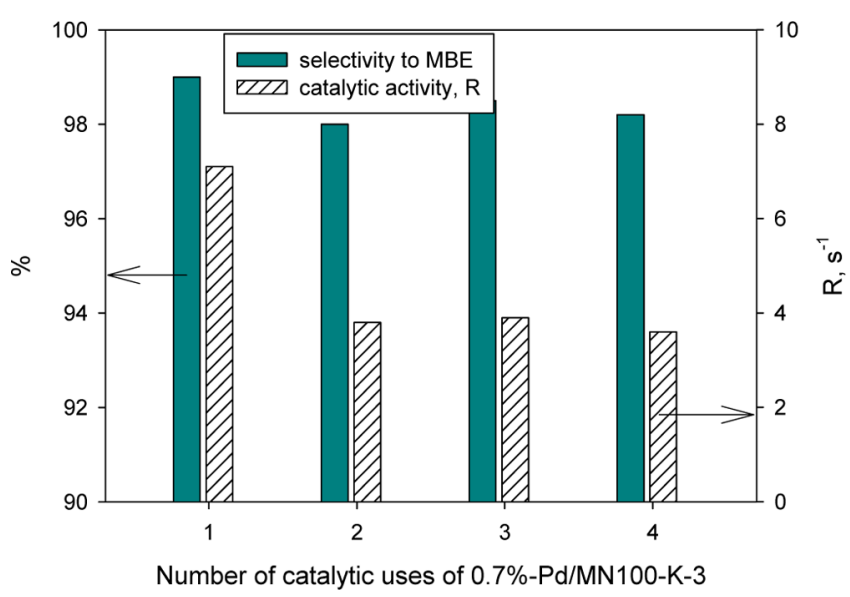

Figure 5. Consecutive reaction runs over the $0.7 \%-\mathrm{Pd} / \mathrm{MN} 100-\mathrm{K}-3$.

Reducing $0.7 \%-\mathrm{Pd} / \mathrm{MN} 100$ with hydrogen (Table 1 , no. 2 ) prior to use also resulted in the elimination of induction period (Figure $3 \mathrm{~d}$ ), with the selectivity of the reaction decreasing to 95.0\%. This is possibly due to differences in the size of the Pd NPs (see section 3.2, HAADF STEM measurements). The in situ liquid-phase reduced Pd NPs have a mean diameter of 4.7 $\mathrm{nm}$ following the reaction of MBY, whereas the hydrogenreduced Pd NPs, performed at $300{ }^{\circ} \mathrm{C}$, are $13.5 \mathrm{~nm}$ in diameter (the optimum size for MBY hydrogenation is considered to be 3-5 $\mathrm{nm}{ }^{5}$ ). The selectivity of MBE obtained with the hydrogen-reduced $0.7 \%-\mathrm{Pd} / \mathrm{MN} 100-\mathrm{R}-\mathrm{K}-3$ catalyst and the reduced $\mathrm{KOH}$-modified $0.7 \%-\mathrm{Pd} / \mathrm{MN} 100-\mathrm{K}-3-\mathrm{R}$ catalyst is the same (94.5\%) with the latter catalyst having a ca. 1.5-fold higher activity (Table 1 , no. 2 and no. 12).

3.2. Catalyst Characterization. X-ray Photoelectron Spectroscopy (XPS). The XPS for the $0.7 \%-\mathrm{Pd} / \mathrm{MN} 100$ reference catalyst (Table 2, Figure S1) reveals the following

Table 2. States of Palladium Found from Modelling of the Pd 3d Band in the XPS Data in Selected Catalysts

\begin{tabular}{|c|c|c|c|c|c|}
\hline \multirow[b]{3}{*}{ chemical state } & \multicolumn{5}{|c|}{ chemical states of Pd on catalyst surface (\%) } \\
\hline & \multirow[b]{2}{*}{$\begin{array}{c}0.7 \%- \\
\mathrm{Pd} / \\
\mathrm{MN} 100\end{array}$} & \multirow[b]{2}{*}{$\begin{array}{l}0.7 \%-\mathrm{Pd} / \\
\text { MN100-R }\end{array}$} & \multicolumn{3}{|c|}{$0.7 \%-\mathrm{Pd} / \mathrm{MN} 100-\mathrm{K}-3$} \\
\hline & & & initial & $\begin{array}{l}\text { after the in } \\
\text { situ } \\
\text { reduction }\end{array}$ & $\begin{array}{l}\text { after the } \\
\text { 1st use }\end{array}$ \\
\hline $\mathrm{PdCl}_{2}\left(\mathrm{CH}_{3} \mathrm{CN}\right)_{2}$ & 42 & 24 & 59 & 44 & 26 \\
\hline $\mathrm{PdCl}_{2}$ & 21 & 8 & 1 & 6 & 3 \\
\hline $\mathrm{PdO}$ & 6 & 32 & 28 & 18 & 9 \\
\hline $\mathrm{Pd}^{0}$ & 7 & 18 & 8 & 11 & 34 \\
\hline $\mathrm{Pd}_{n}$ clusters & 24 & 18 & 4 & 21 & 28 \\
\hline
\end{tabular}

values of binding energy of $\mathrm{Pd} 3 \mathrm{~d}_{5 / 2}: 337.7 \mathrm{eV}$ (corresponds to $\left.\mathrm{PdCl}_{2}{ }^{24}\right)$, $338.6 \mathrm{eV}$ (binding energy of $\left(\mathrm{CH}_{3} \mathrm{CN}\right)_{2} \mathrm{PdCl}_{2}$ was found to be equal $338.7 \mathrm{eV}$ ), $336.1 \mathrm{eV}$ (small clusters of $\mathrm{Pd}$ ), ${ }^{25}$ $335.0 \mathrm{eV}$ (bulk Pd $\mathrm{NPs}^{24}$ ), and $337.1 \mathrm{eV}$ (corresponds to $\left.\mathrm{PdO}^{24,26}\right)$. The $\mathrm{PdCl}_{2}$ is derived from the $\mathrm{PdCl}_{2}\left(\mathrm{CH}_{3} \mathrm{CN}\right)_{2}$ precursor. From the XPS analysis of the $0.7 \%-\mathrm{Pd} / \mathrm{MN} 100-\mathrm{K}-3$ catalyst (Table 2, Figures S3-S5) there is no evidence for the formation of alkali metal-palladium salts such as $\mathrm{K}_{2} \mathrm{PdO}_{2}$ or $\mathrm{KPdO}$, which could potentially be formed during the catalyst preparation.

From the presented data (Table 2 and XPS spectra presented in the Supporting Information) it can be seen that postimpregnation of $0.7 \%-\mathrm{Pd} / \mathrm{MN} 100$ with $\mathrm{KOH}$ results in a sharp decrease of $\mathrm{PdCl}_{2}$ on the catalyst surface (Figure S1 vs S3) concomitant with the increase of $\mathrm{PdO}$ content. Though the rates of reduction of $\mathrm{PdCl}_{2}$ and $\mathrm{PdO}$ to both $\mathrm{Pd}^{0}$ and $\mathrm{Pd}_{n}$ clusters seems to be almost the same, the transformation of $\mathrm{PdCl}_{2}\left(\mathrm{CH}_{3} \mathrm{CN}\right)_{2}$ to $\mathrm{PdCl}_{2}$ is slower leading to slower accumulation of palladium chloride for the modified catalyst (0.7\%-Pd/MN100-K-3) during the reduction with hydrogen in situ and also the subsequent hydrogenation of MBY. This may cause the low concentration of $\mathrm{HCl}$, which is formed as a result of $\mathrm{PdCl}_{2}$ reduction and may inhibit $\mathrm{MBY}$ hydrogenation. It can explain the longer induction period in the case of reference sample $0.7 \%-\mathrm{Pd} / \mathrm{MN} 100$ as compared to $0.7 \%-\mathrm{Pd} / \mathrm{MN} 100-\mathrm{K}-$ 3. After the first catalytic run the $0.7 \%-\mathrm{Pd} / \mathrm{MN} 100-\mathrm{K}-3$ catalyst contains considerably more Pd NPs (Figure S5), which is also consistent with the absence of the induction period observed during the second run (Figure 3).

It is important to underline that the reduction of the $0.7 \%$ $\mathrm{Pd} / \mathrm{MN} 100-\mathrm{K}-3$ catalyst is more efficient during the hydrogenation of MBY as compared to the initial in situ reduction by hydrogen (see Table 2). Recently, it was shown that after the gas-phase reduction of $\mathrm{Pd} / \mathrm{MN} 100$ catalysts, $\mathrm{Pd}^{2+}$ species are observed in the resulting MN100-based samples irrespective of the Pd precursor used. ${ }^{27}$ The $0.7 \%-\mathrm{Pd} / \mathrm{MN} 100-\mathrm{R}$ catalyst, prepared by reduction in hydrogen at $300{ }^{\circ} \mathrm{C}$ also contains different $\mathrm{Pd}$ species (Table 2, Figure $\mathrm{S} 2$ ), that is, $\mathrm{PdCl}_{2}\left(\mathrm{CH}_{3} \mathrm{CN}\right)_{2}, \mathrm{PdCl}_{2}, \mathrm{PdO}, \mathrm{Pd}_{n}$ clusters, and Pd NPs. It is noteworthy that the total percentage of $\mathrm{Pd}_{n}$ clusters and $\mathrm{Pd}$ NPs (36\%) for the $0.7 \%-\mathrm{Pd} / \mathrm{MN} 100-\mathrm{R}$ catalyst is similar to the $0.7 \%-\mathrm{Pd} / \mathrm{MN} 100-\mathrm{K}-3$ catalyst (32\%) after in situ reduction. 

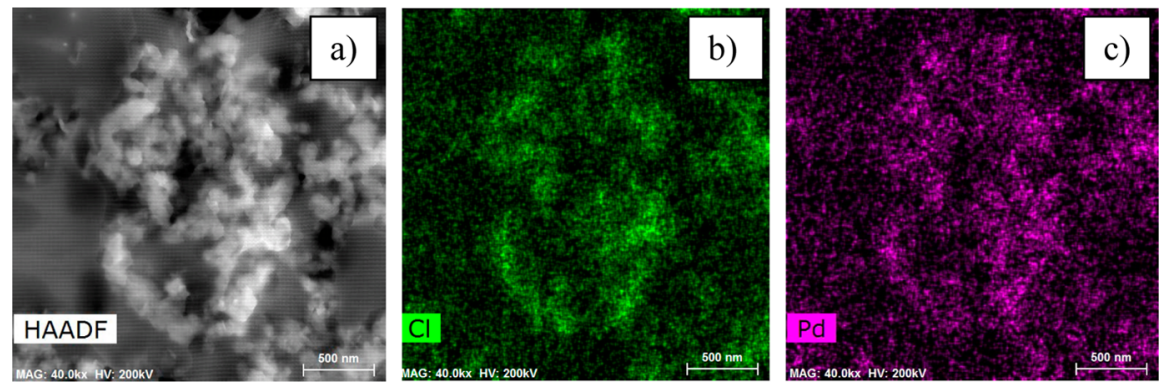

Figure 6. HAADF STEM image (a) and EDX mapping of chlorine (b) and palladium (c) of the 0.7\%-Pd/MN100-Na catalyst.
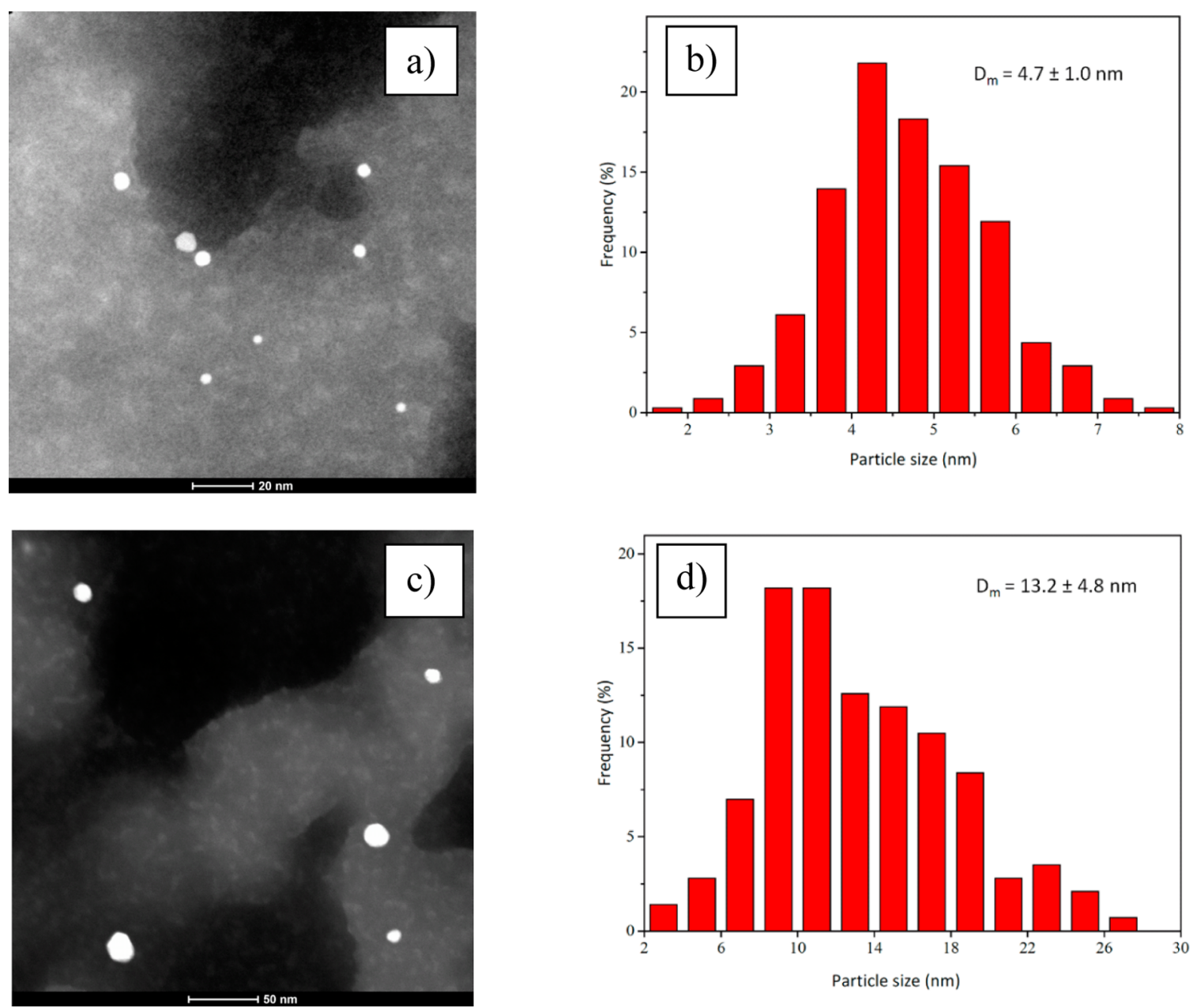

Figure 7. HAADF STEM images and histograms of particle size distributions of the $0.7 \%-\mathrm{Pd} / \mathrm{MN} 100-\mathrm{Na}$ catalyst after MBY hydrogenation (a,b) and the $0.7 \%-\mathrm{Pd} / \mathrm{MN} 100-\mathrm{R}$ catalyst $(\mathrm{c}, \mathrm{d})$.

It was surprising to find unreduced Pd species, especially in the case of the catalysts treated in hydrogen flow at high temperature. Thus, the reference catalyst $1 \%-\mathrm{Pd} / \mathrm{AC}$ was prepared using $\mathrm{PdCl}_{2}\left(\mathrm{CH}_{3} \mathrm{CN}\right)_{2}$ as a precursor and activated carbon $(\mathrm{AC})$ as a support via the same procedure as in the case of MN100. It was found that in the as-synthesized $1 \%-\mathrm{Pd} / \mathrm{AC}$, $\mathrm{PdCl}_{2}\left(\mathrm{CH}_{3} \mathrm{CN}\right)_{2}$ decomposed leaving behind $\mathrm{PdCl}_{2}$ (59.8\%) and metallic $\mathrm{Pd}$ (34.5\%) (Figure S6). After the treatment of this catalyst in $\mathrm{H}_{2}$ flow at $300{ }^{\circ} \mathrm{C}$ for $2 \mathrm{~h}$, only $\mathrm{Pd}^{0}(59.0 \%)$ and $\mathrm{PdO}(41.0 \%)$ were found (Figure $\mathrm{S} 7$ ). Formation of $\mathrm{PdO}$ could be explained by the interaction of $\mathrm{PdCl}_{2}$ with the $-\mathrm{OH}$ containing species of the AC surface being stable under reductive treatment applied.
Therefore, we conclude that MN100 support may stabilize $\mathrm{Pd}^{2+}$ species inside the polymeric network probably due to the interaction with the aromatic rings preventing full $\mathrm{Pd}^{2+}$ reduction under the $\mathrm{H}_{2}$ flow.

High-Angle Annular Dark-Field Scanning Transmission Electron Microscopy (HAADF STEM). In the fresh reference $0.7 \%-\mathrm{Pd} / \mathrm{MN} 100$ catalyst and in the alkali metal modified catalysts no Pd NPs were found. EDX mapping of the $0.7 \%$ $\mathrm{Pd} / \mathrm{MN} 100-\mathrm{Na}$ clearly shows the presence of molecular dispersion of $\mathrm{Pd}$ and $\mathrm{Cl}$ in the HPS (Figure 6).

HAADF STEM images and histograms of particle size distributions of the $0.7 \%-\mathrm{Pd} / \mathrm{MN} 100-\mathrm{Na}$ catalyst recorded after MBY hydrogenation and the $0.7 \%-\mathrm{Pd} / \mathrm{MN} 100-\mathrm{R}$ catalyst are 
shown in Figure 7. For the $0.7 \%-\mathrm{Pd} / \mathrm{MN} 100-\mathrm{Na}$ catalyst the mean diameter of the Pd NPs is $4.7 \pm 1.0 \mathrm{~nm}$ (Figure 7a,b), which is essentially the same size as the Pd NPs in a previously reported $0.7 \%-\mathrm{Pd} / \mathrm{MN} 100$ catalyst $\left(4.5 \pm 0.9 \mathrm{~nm}^{18}\right)$.

In contrast, the $0.7 \%-\mathrm{Pd} / \mathrm{MN} 100-\mathrm{R}$ catalyst contains Pd NPs with a much larger mean diameter of $13.2 \pm 4.8 \mathrm{~nm}$ (Figure $7 \mathrm{c}, \mathrm{d})$. Despite their larger size they are more efficient catalysts for the hydrogenation of MBY, presumably due to the larger content of $\operatorname{Pd}(0)$ as compared to the other catalysts.

To understand the increase of MBE selectivity, the EDX mapping of $0.7 \%-\mathrm{Pd} / \mathrm{MN} 100-\mathrm{Na}$ catalyst after MBY hydrogenation was carried out. The results are shown in Figure 8 revealing that the surface of the Pd NPs is decorated by sodium.
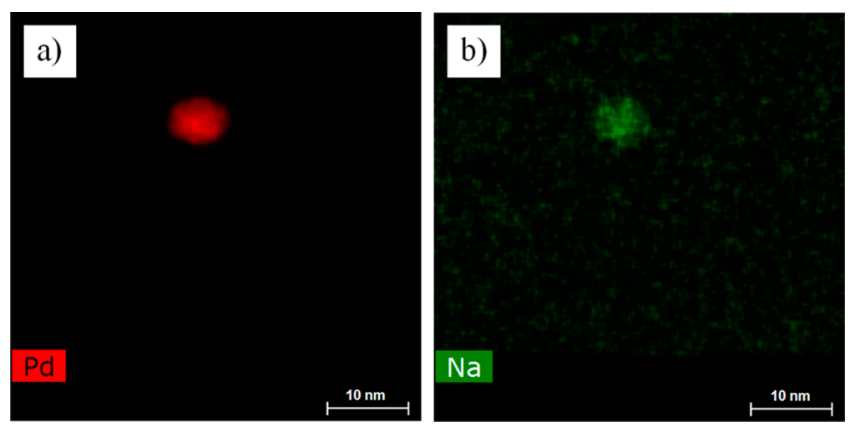

Figure 8. EDX mapping of the $0.7 \%-\mathrm{Pd} / \mathrm{MN} 100-\mathrm{Na}$ catalyst after MBY hydrogenation: distribution of palladium (a) and sodium (b).

However, $\mathrm{Cl}$ is not present on the $\mathrm{Pd}(0)$ NPs surface. The alkali metal ions may interact with the Pd NPs resulting in the site separation. This effect can explain the observed enhancement of MBE selectivity.

DRIFT Spectroscopy of CO Adsorption (DRIFT CO). Figure 9 shows the DRIFT spectra of adsorbed CO for the MN100 starting material and catalysts. Bands corresponding to terminal Pd-CO species are observed in the range 2000 to 2250 $\mathrm{cm}^{-1} \cdot{ }^{28,29}$ The strong vibration is observed at $1900 \mathrm{~cm}^{-1}$ in all the materials and may be attributed to the HPS support, which overlaps with doubly and triply bridging carbonyls and prevents their observation.

As can be seen from Figure 9, after exposure to $\mathrm{CO}$ and purging with $\mathrm{He}$, almost all the $\mathrm{Pd}$ catalysts (the exception is $0.7 \%-\mathrm{Pd} / \mathrm{MN100}-\mathrm{K}-3-\mathrm{R}$ ) contain bands at 2165 and 2228 $\mathrm{cm}^{-1}$, which can be attributed to formation of $\mathrm{Pd}^{2+}$ carbonyl species $\left.{ }^{29}\right)$. Interestingly, the $\mathrm{Pd}^{2+}-\mathrm{CO}$ band is red-shifted to $2191 \mathrm{~cm}^{-1}$ for the sample $0.7 \%-\mathrm{Pd} / \mathrm{MN} 100-\mathrm{K}-3-\mathrm{R}$, suggesting the presence of carbonyls $\mathrm{Pd}^{\delta+}-\mathrm{CO}^{29}$ and a stronger $\mathrm{Pd}-\mathrm{K}$ interaction induced by reductive treatment. ${ }^{8}$

Besides, in many cases two additional bands are observed at 2040 and $2076 \mathrm{~cm}^{-1}$ which may be attributed to CO adsorbing the Pd NPs or $\operatorname{Pd}(0)$ clusters. ${ }^{24,28,30}$ Hence, some samples present both $\mathrm{Pd}(0)$ and $\mathrm{Pd}^{2+}$ sites. It is noteworthy that for the sample reduced with hydrogen directly in the DRIFT cell at a temperature of $300{ }^{\circ} \mathrm{C}$, the existence of the band at $2040 \mathrm{~cm}^{-1}$ is likely due to the formation of bigger Pd NPs or clusters ${ }^{24}$ in comparison with the neighboring band at $2076 \mathrm{~cm}^{-1}$. This observation is in good agreement with the data of XPS and HAADF STEM study showing the formation of Pd NPs with higher mean diameter after the gas-phase reduction in $\mathrm{H}_{2}$ flow at $300{ }^{\circ} \mathrm{C}$ in comparison with the in situ reduction.

\section{CONCLUSIONS}

The effect of alkali metal dopants $(\mathrm{NaOH}$ and $\mathrm{KOH})$ on $\mathrm{Pd}$ NPs stabilized within hyper-cross-linked polystyrene (Pd/ MN100 catalyst) used in the partial hydrogenation of MBY was studied. The addition of $\mathrm{NaOH}$ and $\mathrm{KOH}$ to the $\mathrm{Pd} /$ MN100 catalyst increases both the activity (ca. 1.7 times) and selectivity to MBE (up to ca. 99.5\%) and reduces the reaction induction period. Characterization of the catalysts suggests that the alkali metal hydroxides at low concentrations facilitate the transformation of the $\mathrm{Pd}^{2+}$ residues into $\mathrm{Pd}(0)$, the latter being the active catalytic species. The alkali metal ions also increase the selectivity of the partial hydrogenation of MBY to MBE due to their presence on the Pd NPs surfaces as confirmed by HRTEM-EDX. $\mathrm{K}$ and $\mathrm{Na}$ may interact with the surface of PdNPs resulting in the so-called "site separation effect" which changes the adsorption of reactants. However, at high concentrations the alkali metal ions block the majority of catalytically active sites resulting in a significant decrease of activity.

\section{ASSOCIATED CONTENT}

\section{S Supporting Information}

The Supporting Information is available free of charge on the ACS Publications website at DOI: 10.1021/acs.iecr.7b01612.

XPS spectra (including survey spectra and high resolution spectra of $\mathrm{Pd} 3 \mathrm{~d}$ ) of all the synthesized MN100-based catalysts as well as of the reference catalyst $1 \%-\mathrm{Pd} / \mathrm{AC}(\mathrm{PDF})$

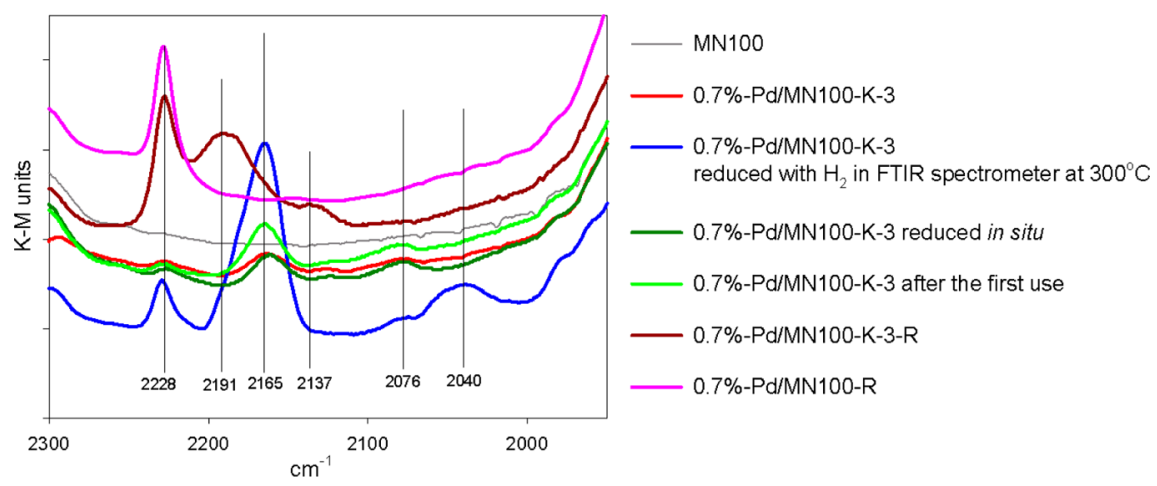

Figure 9. DRIFT spectra of adsorbed CO on the MN100 starting material and catalysts. IR spectra were recorded after exposure to $\mathrm{CO}$ at $10{ }^{\circ} \mathrm{C}$ for $5 \mathrm{~min}$ followed by treatment with $\mathrm{He}\left(100 \mathrm{~mL} / \mathrm{min}, 10{ }^{\circ} \mathrm{C}, 10 \mathrm{~min}\right)$. 


\section{AUTHOR INFORMATION}

\section{Corresponding Authors}

*E-mail: nlinda@science.tver.ru. Tel.; +74822789317.

*E-mail: Lioubov.kiwi-minsker@epfl.ch. Tel.: +41216933182.

ORCID $\odot$

Jeremy S. Luterbacher: 0000-0002-0967-0583

Paul J. Dyson: 0000-0003-3117-3249

Lioubov Kiwi-Minsker: 0000-0002-7192-7212

Notes

The authors declare no competing financial interest.

\section{ACKNOWLEDGMENTS}

Financial support was provided by the Russian Science Foundation (Project 15-19-20023). We thank Ms. Ekaterina A. Kholkina (Tver Technical University, Tver, Russia) for help determining catalyst stability, and Mr. Oliver Anthony Beswick and Mr. Saeed Mohammadi Siyani (EPFL, Lausanne, Switzerland) for help with the HAADF STEM study.

\section{REFERENCES}

(1) Bonrath, W.; Medlock, J.; Schütz, J.; Wüstenberg, B.; Netscher, T. Hydrogenation in the Vitamins and Fine Chemicals Industry - An Overview. In Hydrogenation; Karamé, I., Ed.; InTech, 2012; pp 69-90.

(2) Bonrath, W.; Eggersdorfer, M.; Netscher, T. Catalysis in the Industrial Preparation of Vitamins and Nutraceuticals. Catal. Today 2007, 121, 45 .

(3) Lindlar, H. Ein neuer Katalysator für selektive Hydrierungen. Helv. Chim. Acta 1952, 35, 446.

(4) Witte, P. T.; Berben, P. H.; Boland, S.; Boymans, E. H.; Vogt, D.; Geus, J. W.; Donkervoort, J. G. BASF NanoSelect Technology: Innovative Supported Pd- and Pt-based Catalysts for Selective Hydrogenation Reactions. Top. Catal. 2012, 55, 505.

(5) Kiwi-Minsker, L.; Crespo-Quesada, M. Shape and Size-Tailored Pd Nanocrystals to Study the Structure Sensitivity of 2-Methyl-3butyn-2-ol Hydrogenation: Effect of the Stabilizing Agent. Top. Catal. 2012, 55, 486.

(6) Borodziński, A.; Bond, G. C. Selective Hydrogenation of Ethyne in Ethene-Rich Streams on Palladium Catalysts. Part 1. Effect of Changes to the Catalyst During Reaction. Catal. Rev.: Sci. Eng. 2006, $48,91$.

(7) Yarulin, A.; Yuranov, I.; Cardenas-Lizana, F.; Alexander, D. T. L.; Kiwi-Minsker, L. How to Increase the Selectivity of Pd-based Catalyst in Alkynol Hydrogenation: Effect of Second Metal. Appl. Catal., A 2014, 478, 186.

(8) Pellegrini, R.; Leofanti, G.; Agostini, G.; Bertinetti, L.; Bertarione, S.; Groppo, E.; Zecchina, A.; Lamberti, C. Influence of K-doping on a $\mathrm{Pd} / \mathrm{SiO}_{2}-\mathrm{Al}_{2} \mathrm{O}_{3}$ Catalyst. J. Catal. 2009, 267, 40.

(9) Jia, L.; Bulushev, D. A.; Beloshapkin, S.; Ross, J. R. H. Hydrogen Production from Formic Acid Vapour over a Pd/C Catalyst Promoted by Potassium Salts: Evidence for Participation of Buffer-like Solution in the Pores of the Catalyst. Appl. Catal., B 2014, 160-161, 35.

(10) Cho, H.-B.; Hong, B.-E.; Park, J.-H.; Ahn, S.-H.; Park, Y.-H. Effects of Catalyst Promotion on the Selective Hydrogenation of Biphenol Using Various Pd/C Catalysts. Bull. Korean Chem. Soc. 2008, 29, 2434.

(11) Zhang, W.; Zhu, Y.; Niu, S.; Li, Y. A Study of Furfural Decarbonylation on K-doped $\mathrm{Pd} / \mathrm{Al}_{2} \mathrm{O}_{3}$ Catalysts. J. Mol. Catal. A: Chem. 2011, 335, 71.

(12) Aramendía, M. A.; Burch, R.; García, I. M.; Marinas, A.; Marinas, J. M.; Southward, B. W. L.; Urbano, F. J. The Effect of the Addition of Sodium Compounds in the Liquid-phase Hydrodechlorination of Chlorobenzene over Palladium Catalysts. Appl. Catal., B 2001, 31, 163.

(13) Aramendía, M. A.; Boráu, V.; García, I. M.; Jiménez, C.; Lafont, F.; Marinas, A.; Marinas, J. M.; Urbano, F. J. Liquid-phase Hydrodechlorination of Chlorobenzene over Palladium-supported
Catalysts: Influence of $\mathrm{HCl}$ Formation and $\mathrm{NaOH}$ Addition. J. Mol. Catal. A: Chem. 2002, 184, 237.

(14) Moreno, J. M.; Aramendía, M. A.; Marinas, A.; Marinas, J. M.; Urbano, F. J. Hydrodechlorination of 3-Chloropyridine and Chlorobenzene in Methanol Solution over Alkali-modified ZirconiaSupported Palladium Catalysts. Appl. Catal., B 2005, 59, 275.

(15) Telkar, M. M.; Rode, C. V.; Rane, V. H.; Chaudhari, R. V. Influence of Alkali Metal Doping on Selectivity Behaviour of Platinum Catalysts for Hydrogenation of 2-Butyne-1,4-diol. Catal. Commun. 2005, 6, 725 .

(16) Sabrowsky, H.; Bronger, W.; Schmitz, D. Z. Darstellung und Kristallstruktur von $\mathrm{K}_{2} \mathrm{PdO}_{2}$. Z. Naturforsch., B: J. Chem. Sci. 1974, 29b, 10.

(17) Nemygina, N. A.; Nikoshvili, L. Zh.; Matveeva, V. G.; Sulman, M. G.; Sulman, E. M.; Kiwi-Minsker, L. Pd-Nanoparticles Confined Within Hollow Polymeric Framework as Effective Catalysts for the Synthesis of Fine Chemicals. Top. Catal. 2016, 59, 1185.

(18) Nikoshvili, L.; Makarova, A. S.; Lyubimova, N. A.; Bykov, A. V.; Sidorov, A. I.; Tyamina, I. Yu.; Matveeva, V. G.; Sulman, E. M. Kinetic study of Selective Hydrogenation of 2-Methyl-3-butyn-2-ol over Pdcontaining Hypercrosslinked Polystyrene. Catal. Today 2015, 256, 231.

(19) Nikoshvili, L.; Shimanskaya, E.; Bykov, A.; Yuranov, I.; KiwiMinsker, L.; Sulman, E. Selective Hydrogenation of 2-Methyl-3-butyn2-ol over Pd-nanoparticles Stabilized in Hypercrosslinked Polystyrene: Solvent Effect. Catal. Today 2015, 241 (B), 179.

(20) Sulman, E. M.; Nikoshvili, L.; Matveeva, V. G.; Tyamina, I.; Sidorov, A. I.; Bykov, A. V.; Demidenko, G. N.; Stein, B. D.; Bronstein, L. M. Palladium Containing Catalysts Based on Hypercrosslinked Polystyrene for Selective Hydrogenation of Acetylene Alcohols. Top. Catal. 2012, 55, 492.

(21) Lamy-Pitara, E.; El Mouahid, S.; Kerkeni, S.; Barbier, J. Effect of Anions and Cations on the Aqueous Phase Catalytic Hydrogenation of $\mathrm{C}=\mathrm{C}$ Bonds. Electrochim. Acta 2003, 48, 4311.

(22) Gravelle-Rumeau-Maillot, M.; Pitchon, V.; Martin, G. A.; Praliaud, H. Complementary Study by Calorimetry and Infrared Spectroscopy of Alkali Metal Doped $\mathrm{Pd} / \mathrm{SiO}_{2}$ Solids: Adsorption of Hydrogen and Carbon Monoxide. Appl. Catal., A 1993, 98, 45.

(23) Protasova, L. N.; Rebrov, E. V.; Choy, K. L.; Pung, S. Y.; Engels, V.; Cabaj, M.; Wheatley, A. E. H.; Schouten, J. C. ZnO Based Nanowires Grown by Chemical Vapour Deposition for Selective Hydrogenation of Acetylene Alcohols. Catal. Sci. Technol. 2011, 1, 768.

(24) Wagner, C. D.; Rigs, W. M. Handbook of X-ray Photoelectron Spectroscopy, Perkin-Elmer Corporation, 1979. NIST X-ray Photoelectron Spectroscopy Database, version 4.1 National Institute of Standards and Technology: Gaithersburg, MD, 2012.

(25) Wu, T.; Kaden, W. E.; Kunkel, W. A.; Anderson, S. L. Sizedependent Oxidation of $\operatorname{Pd}_{n}(n \leq 13)$ on Alumina/NiAl(110): Correlation with Pd Core Level Binding Energies. Surf. Sci. 2009, 603, 2764

(26) Paredis, K.; Ono, L. K.; Behafarid, F.; Zhang, Z.; Yang, J. C.; Frenkel, A. I.; Cuenya, B. R. Evolution of the Structure and Chemical State of Pd Nanoparticles during the in Situ Catalytic Reduction of $\mathrm{NO}$ with $\mathrm{H}_{2}$. J. Am. Chem. Soc. 2011, 133, 13455.

(27) Nemygina, N. A.; Nikoshvili, L.; Bykov, A. V.; Sidorov, A. I.; Molchanov, V. P.; Sulman, M. G.; Tiamina, I.; Stein, B. D.; Matveeva, V. G.; Sulman, E. M.; Kiwi-Minsker, L. Catalysts of Suzuki CrossCoupling Based on Functionalized Hyper-cross-linked Polystyrene: Influence of Precursor Nature. Org. Process Res. Dev. 2016, 20, 1453.

(28) Groppo, E.; Agostini, G.; Borfecchia, E.; Wei, L.; Giannici, F.; Portale, G.; Longo, A.; Lamberti, C. Formation and Growth of Pd Nanoparticles Inside a Highly Cross-Linked Polystyrene Support: Role of the Reducing Agent. J. Phys. Chem. C 2014, 118, 8406.

(29) Hadjiivanov, K. I.; Vayssilov, G. N. Characterization of Oxide Surfaces and Zeolites by Carbon Monoxide as an IR Probe Molecule. Adv. Catal. 2002, 47, 307.

(30) Yudanov, I. V.; Sahnoun, R.; Neyman, K. M.; Rösch, N.; Hoffmann, J.; Schauermann, S.; Johanek, V.; Unterhalt, H.; Rupprechter, G.; Libuda, J.; Freund, H.-J. CO Adsorption on Pd 
Nanoparticles: Density Functional and Vibrational Spectroscopy

Studies. J. Phys. Chem. B 2003, 107, 255. 